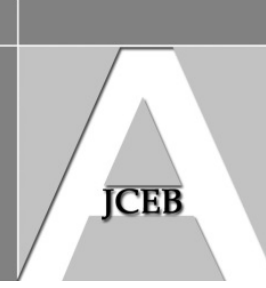

\title{
Sustainable Innovation for Queensland's Housing Design: a Case Study
}

\author{
Michael Johnston \& Mirko Guaralda (School of Design, Queensland University of \\ Technology, Australia) \\ Sukanlaya Sawang (QUT Business School, Queensland University of Technology, \\ Australia)
}

\begin{abstract}
This research provides an assessment tool that assists the selection process of sustainability in detached suburban housing. It investigates the implications of using different design and construction methods including architecturally designed houses, developer housing and prefabricated houses. The study simulates one example of the three types of houses that have been chosen to fulfil a real client brief on a real site on the Sunshine Coast, Queensland Australia. Criteria for sustainability assessment are formulated based on literature reviews, exemplar designs and similar research projects for which the houses can be adequately evaluated. This criterion covers aspects including energy use, materials and thermal performance. The data is collected using computer models and sustainability assessment software to compare and draw conclusions on the success of each house.
\end{abstract}

Our study indicates that architecturally designed housing with prefabricated building techniques are a better alternative to generic developer style housing. Our research provides an insight into the implications of three key elements of sustainability including energy use, materials and thermal performance. Designers, builders, developers and home-buyers are given an insight into some options currently available on the housing market and how the choices made during early design stages can provide a more positive environmental impact.

Keyword: Sustainable housing, prefabricated, perception, attitude, innovation.

\section{Introduction}

Buildings consume enormous quantities of resources and can cause any number of negative impacts to their occupants (Kibert 2012, Arif \& Syal 2013). As the importance of sustainability has become increasingly evident in the built environment industry, designers and construction companies aim to improve building techniques, while maintaining their appeal to customers and within reasonable cost (Oluwole Akadiri and Olaniran Fadiya 2013). Our study aim is to evaluate and compare the design and construction methods of three different houses: architecturally designed, commercial/developer design and prefabricated housing. The purpose is to develop a framework that demonstrates the differences in design and construction methods and the varying environmental implications of each one.

Residential buildings are estimated to contribute $13 \%$ of Australia's greenhouse gas emissions, a figure set to rise $1.3 \%$ per year (Wood 2009). There are currently three main ways in which detached housing is designed and constructed in Australia. The first way is to engage an architect who will design the house based on clients' needs, site conditions, budget, aesthetics and their own expertise (Discoe, Qunii \& Banish 2008). The house then

\footnotetext{
Australasian Journal of Construction Economics and Building 2014. @ 2014 Michael Johnston et al. This is an Open Access article distributed under the terms of the Creative Commons Attribution 4.0 Unported (CC BY 4.0) License (https://creativecommons.org/licenses/by/4.0/), allowing third parties to copy and redistribute the material in any medium or format and to remix, transform, and build upon the material for any purpose, even commercially, provided the original work is properly cited and states its license.
}

Citation: Johnston M, Guaralda M \& Sawang S. 2014. 'Sustainable innovation for Queensland's housing design: a case study', Australasian Journal of Construction Economics and Building, 14 (4), 11-31, http://dx.doi.org/10.5130/ajceb.v14i4.11 
goes to a builder who follows specific directions in the architect's construction details and specification, relying on the architect to manage the project.

The second and more common method is to buy a predesigned house; the clients select a dwelling from a catalogue or in a display village, which is then built at a fixed cost (Zhang et al. 2014). Minor changes can be made to the new house including extra rooms, facade changes, colour changes, kitchen layout and so on, but the basis of the house remains the same (Johnson 2014).

The final method is to use prefabricated modular housing, which is predesigned and arranged to the buyers' requirements and then built in a factory, before being transported and assembled on site. This method is cost effective, quick and claims to be more environmentally friendly than the previous two methods due to controlled construction environments, modular design and eco-friendly materials (Linner \& Bock 2012; Davies 2005).

\section{Prefabricated Housing Background}

Prefabricated housing began in the 1830s when a London carpenter designed and built one for his son to ship to Australia to live in (Blismas \& Wakefield 2009). By $196015 \%$ of American homes were mobile prefabricated houses, but interest in architecturally designed prefabricated housing did not flourish until the mid-90s to 2000s. Leading architects such as Le Corbusier, Walter Gropius, Frank Lloyd Wright, Richard Rogers, Archigram and Kisho Kurokawa have all had a hand in designing and experimenting with prefab's design potential (Arif \& Syal 2013).

In 1945 a series of case study houses began to arise for Arts and Architecture magazine, from which Case Study House \#8 by Charles and Ray Eames emerged (Shulman, Smith \& Gössel 2007). Not only was it a stand out from the other case study houses, but it went on to become one of the most influential and significant houses of the 20th Century due to its innovation of design, construction and functionality (Koenig, Eames \& Eames 2005). Despite their advantages and appeal, most prefabricated modular houses are constructed in rural areas, rather than the typical suburban.

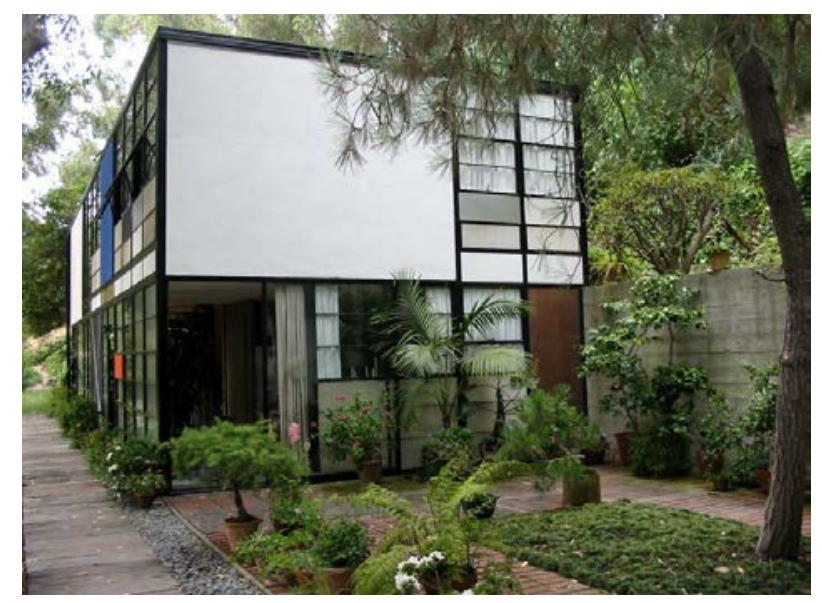

Figure 1: Eames House (case study house No.8),

(Source: eames_court2 by ercwttmn, https://www.flickr.com/photos/ricoslounge/32764430/ Licensed CC by 2.0 http://creativecommons.org/licenses/by/2.0 Taken on 9 August 2005)

\section{Implications of House Location}

The choice of house is not the only factor in establishing sustainable living and lifestyles. Kibert (2008) states that 'In addition to the resources required to build and operate individual buildings, a wide range of additional impacts are the consequence of decisions made as to 
how to distribute buildings across the landscape.' Leaders in sustainable architecture and research Van der Ryn and Cowan (2007) explain in their book Ecological Design that the placement and location of a house is the key to its success as a sustainable living solution.

There is continuous debate over where the most sustainable place to live is. One suggestion comes from the book 'Sustainability and Cities', which outlines the advantages of cities and urban density due to increased public transport and lesser dependence on automobiles (Newman \& Kenworthy 1999). It advocates that planning should discourage car travel, and that a higher density is necessary for limiting road infrastructure which they say is continuing to destroy natural landscapes (Van der Ryn \& Cowan 2007).

Despite the strong argument for density, many Australians still choose to live in detached housing and in suburban areas. Table 1 demonstrates that the majority of people in Brisbane live in houses, except in Brisbane's CBD. This does not suggest that suburbs are better, but simply that people are still choosing to live there. This desire to live in suburbs depends on many factors, some possibilities could include:

- Supply and demand

- Suburbs being developed knowing that people will buy, more profitable to a developer than apartments

- Easy to market

- More appealing to families than an apartment

- Aligns with the 'American dream' that Australian culture is well in tune with

- Aligned with Australia's car culture and a lack of apartments in suburban areas

Table 1: 2011 Suburb profiles for Brisbane

\begin{tabular}{|l|l|l|}
\hline & Brisbane CBD & Brisbane (All suburbs in Brisbane City Council) \\
\hline Population & 13,377 & $\mathbf{1 , 6 2 7 , 5 7 0}$ \\
\hline Detached house & $41 \%$ & $80 \%$ \\
\hline Flat & $41 \%$ & $11 \%$ \\
\hline $\begin{array}{l}\text { Semi-detached/ } \\
\text { Townhouse }\end{array}$ & $7 \%$ & $5 \%$ \\
\hline
\end{tabular}

(Source: www.domain.com.au, accessed on 12 November 2011)

In an interview with Brisbane Times (Moore 2010), the chairman of Brisbane City Council Neighbourhood Planning, Amanda Cooper, stated that 'When families have got children, when they need backyards, they look for a suburban type of experience. And then, as their children grow older, they are thinking that perhaps we need to move back into the inner suburbs.'

The book 'Positive Development' by Janis Birkeland (2002) discusses in depth some of the contradictions of high density living in cities. Reduced car travel and nearby amenities are often associated with urban sustainability, but too many variables and contextual factors mask the truth about the social and environmental impacts of such developments. Urban sustainability has been focused on density and form, using zoning and land uses from an aerial planning view to dictate where buildings should go favouring modernist style structures that unify design to their most simplistic and efficient form (Kendall 1999). Birkeland uses shopping centres to clarify the contradictions, stating that bringing 'more residents into the city, while allowing more shopping and recreation facilities in the suburbs, has created a vicious circle', leaving city residents with more fast food and less fresh food supermarkets. The question is then raised: 'what is the critical variable in urban sustainability, if not increased density?' to which Birkeland simply answers 'design'. 
Part of this design process is assessing the needs of the client, in particular the size and room requirements of the house (Öst 2012; Schneider \& Till 2005). The 2013 median land size reported by the Urban Development Institute of Australia (2014) for new houses across the five major capital cities in Australia, is $423 \mathrm{~m}^{2}$. In Brisbane, the average land size for new houses in 2013 is $451 \mathrm{~m}^{2}$, which is down from the 2012 average of $515 \mathrm{~m}^{2}$ and considerably smaller than the 2006 average of $600 \mathrm{~m}^{2}$. Professor and author of sustainable construction, Charles J. Kibert, believes the environmental implications of the building industry need rethinking, especially the needs and size requirement of buildings. Kibert raises two key questions: 'is the building actually needed, or is adequate space already available?' and 'Can the building be made smaller?' when discussing the initial steps to reducing a buildings carbon footprint (Kibert 2012).

Using the infrastructure that is currently in place, what difference would it make simply changing the initial design and construction technique of a house? Landscape architect and regional planning writer Ian McHarg (1981) suggests that existing urban areas should remain, as they are already established with infrastructure and need to ensure that open space is maintained and kept public. What kind of changes can be made with selecting different materials, changing mind sets and altering life choices even slightly? If each family were to make more sustainably conscientious decisions when building a house in suburbia, carbon emissions could be greatly reduced.

\section{Exemplar Housing Projects}

A pilot research on three exemplar projects has informed the research techniques and framework used in the main study. A comparative analysis of these case studies has exemplified current research limitations in this field. The exemplar projects include (a) architecturally designed house, (b) commercially designed house and (c) prefabricated house.

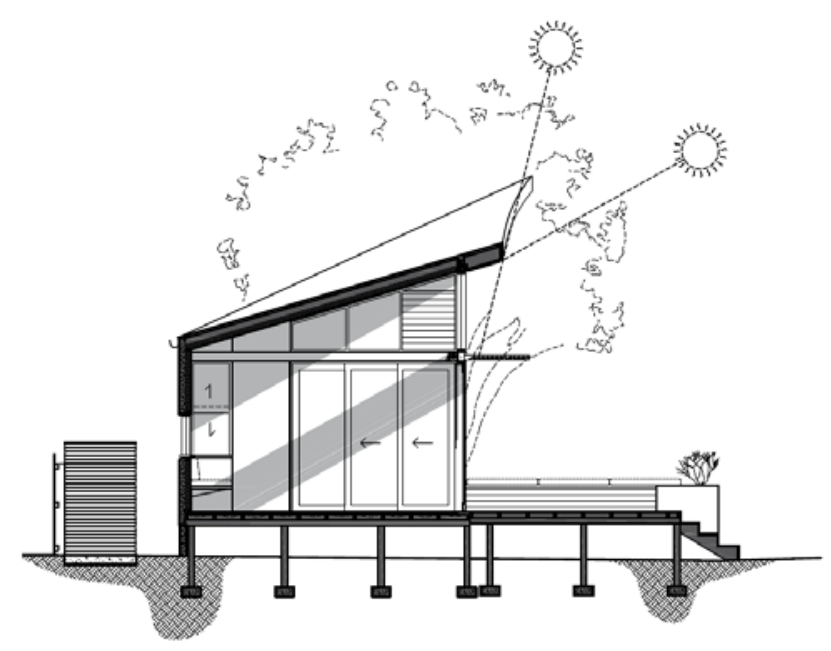

Figure 2: Daylight study for Brighton Compact (Callery \& Bartak 2010)

\section{Architect House Exemplar}

Brighton Compact green house by Zen Architects is an example of an architecturally designed house that employs simple passive solar design principles and material choices to create a highly efficient building (Figure 2). The architects utilised energy rating systems early in the design process that allowed design alterations like room arrangements, ceiling heights, adding insulation, double glazing and thermal mass to be tested. Wary that the current rating systems are designed to bring houses that perform badly to a minimal 
standard, the architects aimed for a higher environmental performance beyond Greenstar or NABERS rating tools, with the help of computer software. The software used to rate the Brighton house favours less windows and more thermally efficient box designs, but other considerations such as views, day-lighting and architectural delight are not taken into consideration by the computer. This house includes passive solar design, and rooms are north orientated to maximize the solar gain.

\section{Commercial Designed (Developer) House Exemplar}

GreenMode, an organisation focused on economic and environmental improvements, performed a study that involved improving the sustainability of 35 'typical' South-East Queensland homes (Divecha, Muffet \& Grant 2008). The study was carried out in alliance with RMIT University, Queensland Environmental Protection Agency and developers Delfin Lend Lease. The results found that drastic improvements could be made with proprietary changes, without having to redesign the house or spend a lot of money. Software called FirstRate 5 and SimaPro was used to simulate a variety of improvements made by the following list of changes (Figure 3):

1. Space heating and cooling - best of two orientation for home, double glazing and auto window shades, insulation and heat reflective paint, roof and room ventilation, 6 star air conditioning, ceiling fans and kitchen \& bathroom extractor fans

2. Domestic Hot water - gas boost solar hot water

3. Appliances - high efficiency appliances, 3 star improvement in all appliances

4. Lighting - energy efficient lighting

5. Renewable onsite energy - 1kw solar PV system

6. Home construction - NRG Greenboard style wall construction, $60 \%$ concrete recycling rate at end of building life

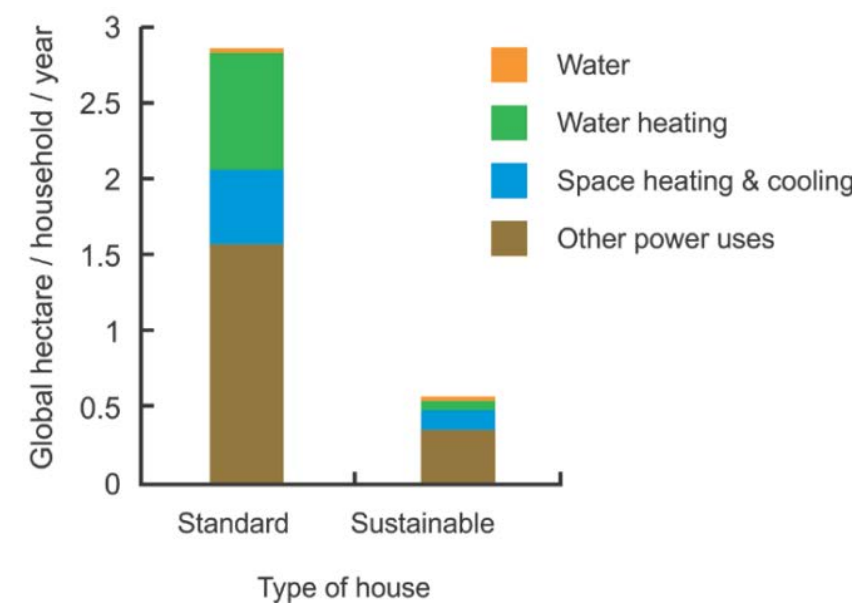

Figure 3: House footprint results - average across 35 typical project home designs (Divecha, Muffet \& Grant 2008).

\section{Prefabricated House Exemplar}

Breezehouse by Michelle Kaufmann is an early example of 21st century prefab housing. The highly praised house features environmentally friendly materials, high ceiling and windows for natural light as well as unique glass sliding doors developed to bring the outdoors in (Kaufmann \& Remick 2009). One of the major embodied principles is the use of 'smart design', which, just as Kibert suggests, involves minimising the size of the house to drastically reduce its carbon footprint (Figure 4). 'Design big, don't build big', as it is 
suggested that greater internal heights, logically placed rooms and a connection to the outside environment will make a house feel bigger naturally (Kaufmann \& Remick 2009).

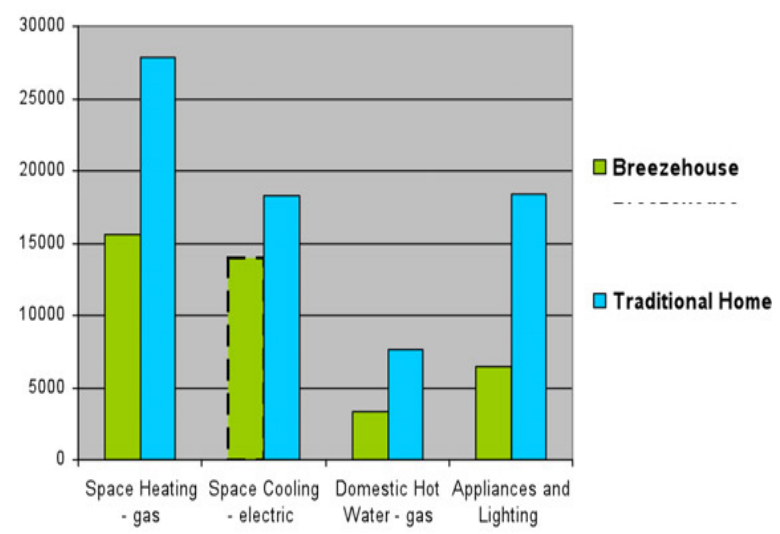

Figure 4: Breezehouse sustainability rating (Kaufmann and Remick 2009)

\section{Existing Research Limitations}

As the exemplar projects have demonstrated, current research is limited to studies between architecturally designed houses vs non-architecturally designed houses, traditional vs prefabricated housing and developer housing vs developer housing with sustainable improvements. For designers, builders and home-buyers this disjointed research can be confusing, in-depth and difficult to access, usually available from the companies attempting to promote their own product. The gap between those interested in architecturally designed housing and off-the-shelf housing is bridging further apart and many people are left unaware of the choices available to them and the impacts these decisions can make. There is currently a lack of independent research that relates to design and construction methods that reduce the carbon footprint and improve on living sustainably.

The research for this project is a comparative analysis between 3 different houses, each designed and constructed using different methods. A real site with a real client sets the constant variable for which the architect house was designed and constructed. The other 2 houses, a developer house and prefabricated house, are matched as closely as possible to fulfil the clients brief.

\section{Framework Development}

In formulating criteria for assessing this research project, many principles of sustainable design and construction were researched to understand how to assess the sustainability of a house. Along with the list outlined in the GreenMode study, aspects of the following two lists have ultimately informed the final criteria for this research project.

Kibert (2005) believes that the construction industry is currently too focused on making low cost, rapidly constructed buildings without any attention for quality or sustainability. He states that changing mind-sets is a huge challenge and that the norm of demolishing and landfilling buildings at the end of their useful life needs major rethinking.

Kibert's book Sustainable Construction: Green Building Design and Delivery, outlines the seven principles of sustainable construction:

1. Reduce - Reduce resource consumption

2. Reuse - resources

3. Recycle - use recyclable resources

4. Protect nature 
5. Eliminate toxins

6. Economics - apply life-cycle costing

7. Quality - materials and finish

House designers from Eco-Logical Building (http://www.ecologicalbuilding.com.au) provide a list of factors that they incorporate into their designs for clients who want a house optimised for energy efficiency. According to the designers from Eco-Logical Building, these factors are specific to ecological residential design:

1. Orientation

2. Low impact construction techniques using sustainable building materials wherever possible

3. Passive solar design ensuring reduced greenhouse gas emissions and energy cost savings

4. Appropriate glazing to windows, providing thermal protection and higher acoustic ratings

5. Higher levels of insulation

6. Grey water recovery systems

7. Solar/wind energy options

8. Efficient site waste management

The criteria for this research will focus on aspects of each of the lists, including:

1. Energy consumption, as per Greenmode's first point concerning space heating and cooling.

2. Materials according to Kibert's list and Eco-logical's second point. This will consist of the major components of house construction.

3. Thermal performance, as outlined by points 1-5 in Eco-logical's list.

\section{Methodology (Case study)}

\section{Site and Houses for this Study}

The site is located in Noosa, Southeast Queensland, on a small suburban development $160 \mathrm{~km}$ north of Brisbane. Noosa is located in a sub-tropical climate, with temperatures ranging between 17 to $28^{\circ} \mathrm{C}$ in summer and 7 to $22^{\circ} \mathrm{C}$ in winter. The site is narrow with a frontage of less than $20 \mathrm{~m}$, tapering to $12 \mathrm{~m}$ at the back and $25 \mathrm{~m}$ long, with views of parklands to the north at the back. The total area of the site is $475 \mathrm{~m}^{2}$ including setbacks. The dimensions and details of the house and site are provided by the architect. The brief is provided courtesy of the architect who took on the client and designed the house, known as 'architect house' in this study.

1. Meticulously designed contemporary house where the design encompasses comfort, casual lifestyle, class and sophistication.

2. Modern with a minimal 'boxy' look.

3. Designed for a couple with 2 children.

4. Living areas should be open plan to maximise natural ventilation (it is likely that airconditioning will be required but designed sensitive to architecture and neighbours.

5. Positioned to take advantage of parklands and best orientation.

6. Living areas should open onto outdoor entertainment areas and pools where stipulated. 
7. First class kitchen is required and should be the centre of the living experience.

8. Main bedroom/ensuite/robe area interfaces to be 'special' i.e. separate and with views and unique materials.

9. Double garage and double storey.

10. Welcoming entry.

11. House site cover, setbacks and heights governed by Council approved conditions.

This house is chosen for its flat site and relatively simple design that could be closely matched with 2 other types of houses. The design is fairly 'typical', with no ground-breaking sustainable technologies and the only unique feature being the use of full height glazed curtain walls. The house instead relies on clever design in terms of orientation, window location, room arrangements, playing with heights and a clean minimal palette of materials that keep it special without over embellishing. House information is provided in Table 2.

\section{Implementing Software}

As with the Brighton Compact case study and GreenMode study, the method for comparing the three houses is based on using specific software. The evaluation software produces results in a common unit of measure which can be compared and evaluated. The three software packages include:

- Archicad is used to create a Building Information Model (BIM) of each house from existing 2D plans, including heights, materials, quantities and orientation. The BIM is exported to other software packages to calculate sustainability analysis.

- Ecodesigner is an add-on within Archicad, able to produce energy balance evaluations based on the BIM model. This produces energy consumption quantities and energy costs in the common unit of measure, $\mathrm{CO} 2 \mathrm{e}$.

- eTool evaluates each house based on the BIM, able to measure and calculate the quantity of materials and their carbon emissions. eTool takes into consideration a number of factors for each material that affects its performance, including assembly, operational, transport and recurring. The final output for each house is given in the common unit of measure, CO2e, as well as kWh/a and Australian dollars (AUD).

From the case studies and background research, a list of criteria has been devised to rate the performance of each house, including:

1. Energy Consumption (i.e. heating and cooling).

2. Materials (i.e. floor, wall, internal, roof, reuse, recycle, reduce).

3. Thermal (i.e. orientation, ventilation, solar gain/exclusion).

Under these three aspects, the results generated from the software are laid out graphically in diagrams and charts, followed by a discussion outlining reasons for the results, discrepancies, and comparisons. 
Australasian Journal of Construction Economics and Building

Table 2: Comparative information of three house exemplars

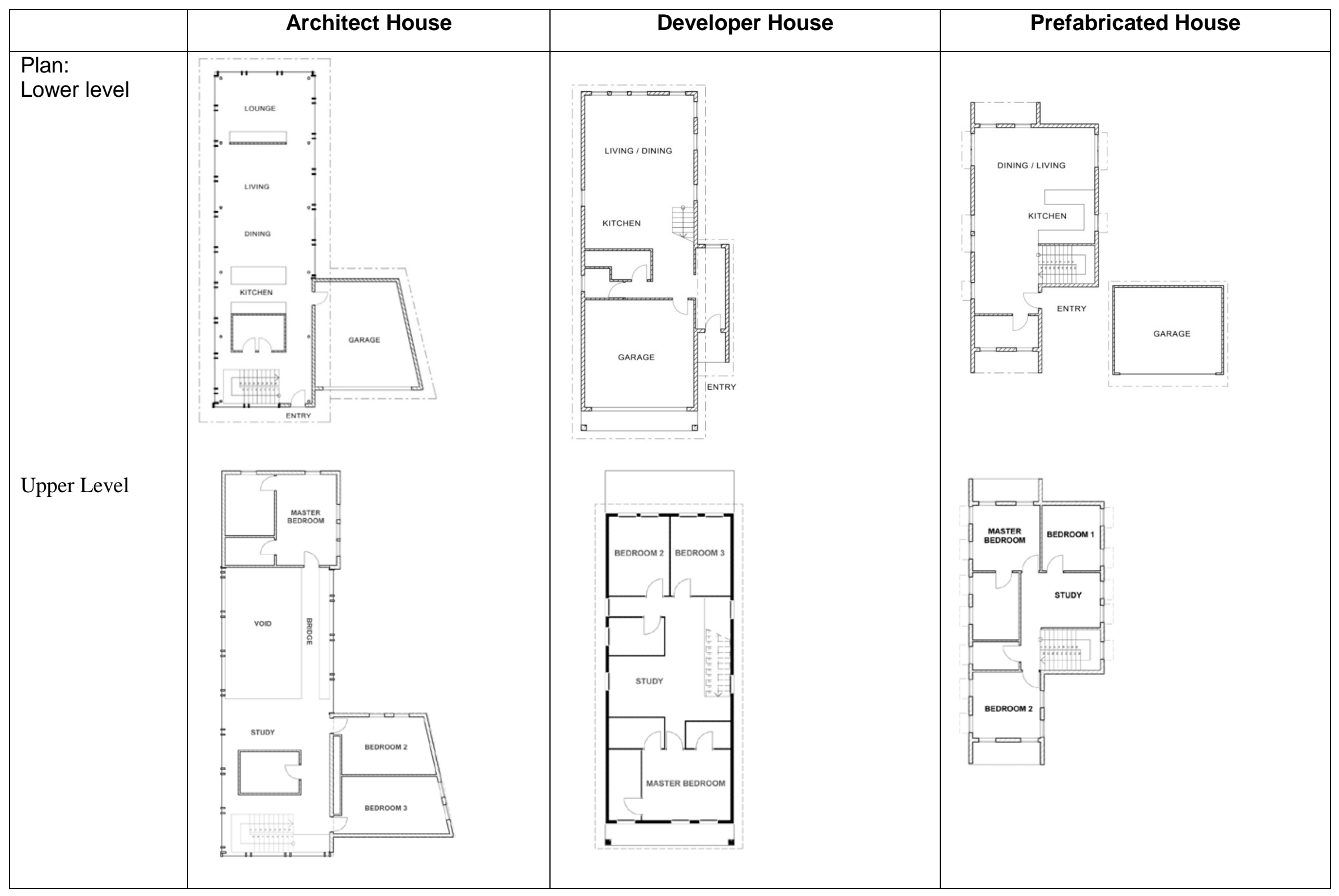




\begin{tabular}{|c|c|c|c|}
\hline & Architect House & Developer House & Prefabricated House \\
\hline Design: & $\begin{array}{l}\text { The architect house sets the } \\
\text { benchmark for this project; an } \\
\text { architect was engaged to design } \\
\text { and project-manage the } \\
\text { construction of this house, working } \\
\text { closely with the client to ensure } \\
\text { every feature was to their liking. } \\
\text { The documentation is traditional } \\
\text { style, with a set of tender drawings } \\
\text { being issued to find a builder } \\
\text { acceptable to complete the project } \\
\text { at a reasonable price. }\end{array}$ & $\begin{array}{l}\text { A number of house developers' } \\
\text { designs have been evaluated and the } \\
\text { selected one is comparable to the } \\
\text { solution provided by the architect case } \\
\text { study. The developer has } 4 \text { house } \\
\text { designs that are narrow enough to fit } \\
\text { on the site, and has one with a } \\
\text { reasonable layout. A few facade } \\
\text { options are available, for consistency } \\
\text { the 'boxy modern' style is chosen. } \\
\text { The builder and designer are all within } \\
\text { one company, so no tender process is } \\
\text { necessary and the price is fixed } \\
\text { upfront. }\end{array}$ & $\begin{array}{l}\text { The prefab house is chosen due to its } \\
\text { range of available modules, the ways } \\
\text { in which the modules can be arranged } \\
\text { and site suitability. The house } \\
\text { modules have been designed by a } \\
\text { renowned and highly awarded } \\
\text { architecture firm located in Brisbane } \\
\text { and supplied through a local company } \\
\text { who make design alterations and } \\
\text { provide a fixed price upfront. }\end{array}$ \\
\hline Construction: & $\begin{array}{l}\text { The construction is traditional } \\
\text { style; some elements of the } \\
\text { house are prefabricated, while } \\
\text { others are cut to size on site. }\end{array}$ & $\begin{array}{l}\text { The construction is traditional style; } \\
\text { some elements of the house are } \\
\text { prefabricated, while others are cut } \\
\text { to size on site. }\end{array}$ & $\begin{array}{l}\text { The construction is completely } \\
\text { prefabricated in a controlled factory } \\
\text { into modules and then delivered on } \\
\text { site, where it is assembled by a } \\
\text { small team. }\end{array}$ \\
\hline Size: & 325 m2 & $235 \mathrm{~m} 2$ & $230 \mathrm{~m}^{2}$ \\
\hline Cost: & $\$ 640,000$ & $\$ 350,000$ & $\$ 370,000$ \\
\hline Cost per m2: & $\$ 1970$ & $\$ 1490$ & $\$ 1608$ \\
\hline
\end{tabular}


Australasian Journal of Construction Economics and Building

\begin{tabular}{|c|c|c|c|}
\hline & Architect House & Developer House & Prefabricated House \\
\hline \multicolumn{4}{|l|}{ Materials: } \\
\hline Cladding & $\begin{array}{l}\text { Timber battening (garage and } \\
\text { bedrooms) and zinc (master } \\
\text { bedroom), glass curtain walls }\end{array}$ & Brick Veneer from Austral & Plywood cladding - stained \\
\hline Roof & Custom Orb Colorbond & Custom Orb Colorbond & Custom Orb Colorbond \\
\hline Floors & $\begin{array}{l}\text { Tiles downstairs and wet areas, } \\
\text { hardwood upstairs }\end{array}$ & $\begin{array}{l}\text { Tiles throughout, carpet in } \\
\text { bedrooms }\end{array}$ & $\begin{array}{l}\text { Hardwood throughout, tiles in wet } \\
\text { areas }\end{array}$ \\
\hline Doors & Timber & Timber & Timber \\
\hline Internal Finish & $\begin{array}{l}\text { Plasterboard with matt paint finish } \\
\text { and curtain walls }\end{array}$ & $\begin{array}{l}\text { Plasterboard with acrylic paint } \\
\text { finish }\end{array}$ & Plasterboard with matt paint finish \\
\hline Insulation & Yes & Yes & Yes \\
\hline
\end{tabular}




\section{Findings and Discussions}

The study simulated one example of the three types of houses that were chosen to fulfil a real client brief on a real site on the Sunshine Coast, Queensland Australia. Criteria for sustainability assessment were formulated based on literature reviews, exemplar projects and similar research projects for which the houses could be adequately evaluated. This criterion covered aspects including energy use, materials and thermal performance. The data was collected using computer models and sustainability assessment software to compare and draw conclusions on the success of each house as below.

\section{Energy Consumption}

The following three graphs are results from Ecodesigner based on the BIM in the specified location of Noosa Queensland. Figure 5 shows that the developer house uses more energy each year than the other two, despite being almost the same size as the prefabricated house and $90 \mathrm{~m} 2$ smaller than the architect house. To make comparative assessments between the energy use and materials, the results will now be displayed in $\mathrm{CO} 2 \mathrm{e}$, the common unit of measure. The cooling and heating energy are combined into a total amount.

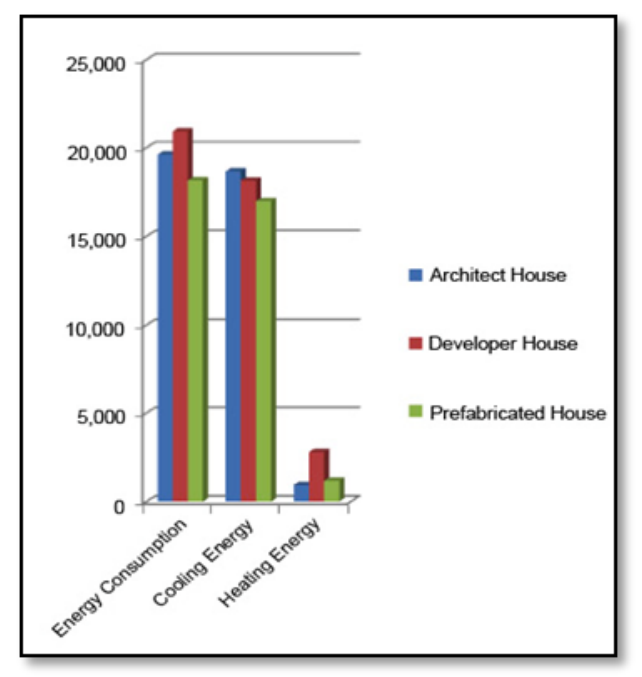

Figure 5: Energy consumption measured in kWha2

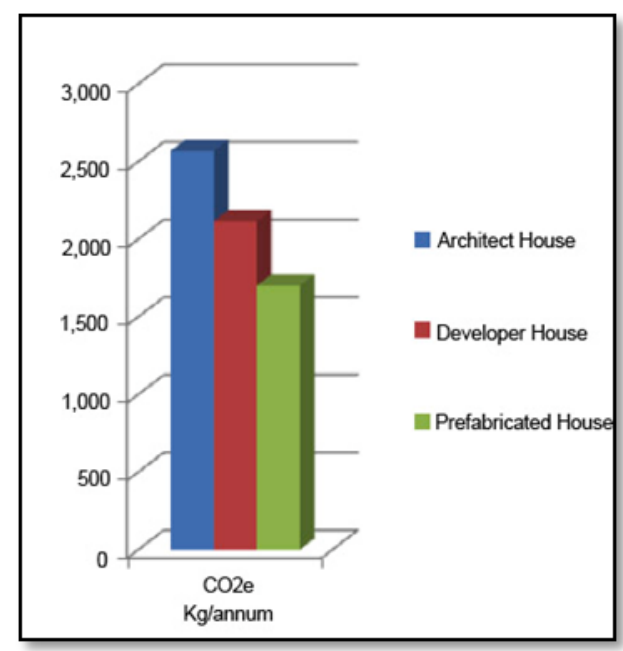

Figure 6: CO2e (kg/annum) of each house

Figure 6 shows expected results, as the architect house is $90 \mathrm{~m} 2$ larger than the other two houses. The architect house uses about $20 \%$ more energy per year than the developer house, and the developer house uses about 20\% more energy per year than the prefabricated house. By displaying the information in $\mathrm{kg} / \mathrm{m} 2$ the difference in size is taken 
out of the equation and a fairer comparison can be made of the performance. If the architect house were the same size as the other two houses it would perform better than the developer house, but still not as well as the prefabricated house.

\section{Materials}

Figure 7 shows the results of the analysis from eTool in factors of carbon emissions $(\mathrm{CO} 2 \mathrm{e})$ over a 100 year life of the building. The total amount is broken into the four major contributors of the buildings carbon emissions, notably the floors and walls. The results show that the prefabricated house is the most sustainable house overall. The developer house and the architect house have similar total CO2e's, despite the architect house being $90 \mathrm{~m} 2$ bigger. By breaking down the major components of the houses, the reasons for the total amount become clear.

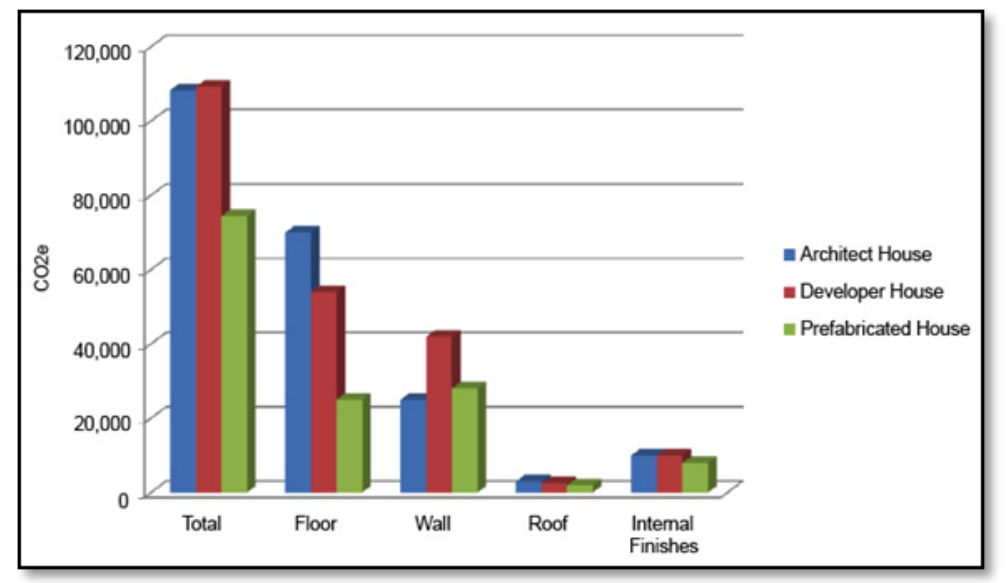

Figure 7: $\mathrm{CO} 2 \mathrm{e}$ of materials in each house

The architect house and prefabricated house have been designed for south-east Queensland by local Brisbane architects. The materials are appropriate for the climate and have been chosen specifically to suit to the site. The developer house on the other hand is not specific to the site or the climate, as the same house can be bought in other states of Australia. Houses situated in sub-tropical climates benefit from light construction techniques with low thermal mass. The use of concrete slabs is less desirable than elevating the house with timber floors on stumps as seen with the prefabricated house.

\section{a) Floor:}

Concrete is used most extensively in the architect house due to its larger size, but could be reduced to the amount of the developer house by reducing its floor area. The floor in the prefabricated house is constructed from timber and elevated off the ground, as opposed to a concrete slab used by the other two houses. This results in a significant $\mathrm{CO} 2 \mathrm{e}$ reduction due to timber's sustainability and recyclability. Timber could be improved by utilising recycled timber in the floor structure, walls and finishes, an opportunity missed by every house.

\section{b) Wall:}

What the architect house loses in floor construction is made up for in wall construction, as it uses timber cladding and thin sheet metal instead of the brick veneer that is used to clad the developer house. The majority of the architect house is glass curtain wall and louvres, a system which is not structural and can be seen in many modern skyscrapers. Instead, most of the structure is supported by steel columns spaced at $4 \mathrm{~m}$ centres and drastically reduces the need for stud walls with external and internal cladding. The prefabricated house has a 
timber frame structure like the developer house, but is clad in timber boards instead of brick, reducing its $\mathrm{CO} 2 \mathrm{e}$ significantly.

\section{c) Internal Finishes:}

Each house has a similar amount of internal finishes including plaster on the walls and ceiling, paint on the walls and ceiling, and tiles in the bathrooms. The architect house and prefabricated house use timber floors throughout the majority of the house including the bedrooms, while the developer house uses tiles throughout and carpet in the bedrooms resulting in a higher $\mathrm{CO} 2 \mathrm{e}$.

\section{d) Reuse:}

To reuse something is to utilise the product in its original form as a whole, for example using old speakers on a new amplifier (MacMillan 2006). Kibert (2005) explains reuse in sustainable architecture as 'Keeping materials in productive use, which also implies keeping buildings in productive use'.

Many components from the architect house can be dismantled and reused, including the windows, curtain walls, doors, cladding, timber upstairs and part of the steel posts. The only piece remaining would be the concrete slab, which would have to be dismantled in many pieces and recycled, not re-used. An example of how to reuse is the large expanses of glass becoming a shop front or partitions in an office. This is a level of creative thinking that goes beyond the analysis of software and is only possible with the house designer's intent, careful planning and recommendations of ways to recycle the house. The thought that goes into the initial design process will provide more inspiration when it comes time to dismantle the house.

The developer house has fewer components to reuse as it is slab on ground with brick veneer. It is very difficult to dismantle brick veneer, as it is fixed together and cannot be taken apart brick by brick. The house has an advantage of being made up of standardised components, such as windows and doors, which are used in many developer houses. The timber frame could essentially be re-used, but is more likely to be recycled into something non-structural.

The prefabricated house can be deconstructed and carted away to a different site for another use, as modular pieces are the easiest to disassemble and reuse. The prefabricated house would have to be dismantled in the same way it was assembled and taken away as complete modules. These can be easily relocated to prolong the life of the building and will leave behind nothing but footings and a small slab for the carport.

\section{e) Recycle:}

Recycling is different to reuse as to recycle something is to destroy the product and reuse it as parts, for example taking the parts of an old mobile phone and melting down the metals to make a new phone (MacMillan 2006).

Recycling would be less likely for the houses as most of the parts can be reused instead. The concrete slabs are very difficult to recycle as they are permanently fixed to the ground, but could be broken up and made into new recycled concrete. Other elements that would normally be reused could be recycled, such as the glass could be broken down and made into new glass. The zinc cladding from the architect house could be destroyed and made into a new cladding or used for something entirely different.

\section{f) Reduce:}

Ranging between $230 \mathrm{~m}^{2}-325 \mathrm{~m}^{2}$, each house is well reduced in size and situated on a block of $475 \mathrm{~m}^{2}$, which is within the Brisbane average size of new blocks for 2012-2013. Although, it is important to note that the house was completed in 2006, when the average block for 
Brisbane was $600 \mathrm{~m}^{2}$, making the block quite small for its time. As highlighted previously, the architect house uses glass curtain walls that reduce material use, avoiding cladding, structural timber, plaster and paint. Another example of reduction is the use of a flat roof, which does not require large trusses to achieve the pitch of the developer house, using less timber and less roofing material. Simple techniques like this assist in reducing the amount of materials that go into building a house.

\section{Thermal Performance}

Thermal performance will be calculated based on site and plan analysis. The architect house is the only house designed from the ground up to suit the site and climate, while the other two houses are limited on how they can adapt to take advantage of the orientation and surrounding areas. The first rule for sustainable designs in Van der Ryn and Cowan's Ecological Design is 'Solutions grow from place', a design principle that means each house must, in a way, be unique (Van der Ryn \& Cowan 2007).

A sustainable house cannot succeed without some level of site specific customisation, as the more connected a house is to its site, the more it will thrive in capturing and using nature. This can be achieved from design by architects and building designers, partly from prefabricated modular design and not at all from generic predesigned houses. So much of houses' sustainable success derives from thermal performance which is directly related to orientation, sunlight and ventilation.

\section{Architect House $^{1}$}

\section{a) Orientation/Room arrangements:}

The architect house has been designed to maximise thermal performance by carefully arranging each room based on orientation, use and relationships with other rooms. The main circulation space is placed near the entry on the south side, which includes entry from the street, entry from the garage, vertical circulation to the bedrooms and study via the stairs, concealed laundry and guest bathroom, and direct access to the large double height open plan living area. The open living area faces north-east and west, but has been positioned on site so that the outdoor area is on the east and features glass sliding doors. The west side is more sheltered from the sun because of the close proximity to the fence line and neighbouring house, and has a facade that allows less heat in. The lounge room at the northern most point of the house enjoys the best orientation and is flooded with light, and is cross ventilated east to west. Because of the form, construction techniques and triangulated site, the garage has been placed on the east side, when generally the best place for a garage is the west side as it is rarely occupied and can act as a thermal barrier.

The second and third bedrooms are above the garage which gives them a north - north-east aspect, a benefit achieved from the garage also being on this side. This wing of the building gives privacy from the street to the rest of the house including the glass clad eastern facade of the open plan living area and the outdoor area. A bridge spans the double height void over the open plan living and connects to the master bedroom. The bedroom overhangs the rest of the house and is isolated via the bridge, giving it the 'special' aspect that the client required. The room faces north east and has an ensuite and wardrobe on the west to block sun on this side.

\section{b) Ventilation:}

The window to wall ratio of the architect house is significantly higher than the other two, with majority of the open plan area having full height glazing and a large double height atrium

\footnotetext{
${ }^{1}$ Elysium house by Woods Bagot used with permission by Mark Damant
} 
over the open plan living area. Much of this glazing includes full height louvres that allow breezes and cross ventilation to pass through the house very easily.

Due to large quantities of louvres and cross ventilation, mechanical ventilation is not needed for the open living areas. All the bedrooms are facing north-north-east and have ceiling fans for when there is little wind.

The double height void allows hot air to rise rapidly and vent through open louvres, rather than linger down at human height.

\section{c) Solar:}

Large expanses of glass allow a great amount of light into the architect house, which reduces the need for artificial lighting. This can have negative connotations, as too much sunlight can bring excessive heat into the house, increasing the need for mechanical ventilation. To overcome this, the house has $1 \mathrm{~m}$ roof overhangs all around that block sunlight in summer, and allow desirable amounts in during winter, due to the sun being lower in the sky. The louvres on the upper level of the house are heavily tinted on the east and north sides, and metal on the west to completely block out the harsh western sun. The occupants have the freedom to change the angle of the louvres to allow or block certain levels of light and wind, which can be done depending on the direction on particular days.

\section{Developer House ${ }^{2}$}

\section{a) Orientation/Room arrangements:}

Choosing a developer house avoids the design stage, and many people will base their layout decisions to suit their lifestyle, without considering the parameters their site provides. If the site is not running in the direction that the pre-designed house is suited for, there will be complications. For example, the developer house chosen for this study had the living room leading out to an outdoor area on the north side, but due to the client's needs this had to be filled in to become a second living space. The outdoor alfresco area could no longer exist there and had to move to the east side, acceptable for this design but if there was a requirement for a covered outdoor area then it would have to be built outside the building envelope increasing costs and adding extra roof. A problem with only being able to mirror predesigned houses along one axis means outdoor and living areas can end up in undesirable orientations, potentially increasing the need for heating or cooling.

To suit the site, the developer house design has been mirrored along the north-south axis, putting bathrooms, laundries and kitchen on the western side and the bedrooms on the east. The whole house fits into a single building envelope apart from the entry foyer. The garage sits on the southern side, and the layout of the bottom floor is similar to that of the architects design. The house lacks the double height void and the large expanses of windows, opting for standard sliding windows and one sliding door leading to the outdoor area. This area remains exposed as the garage is not blocking it from the street.

Upstairs features the same number of rooms as the architect house, but are more compressed and have a different layout. The second and third bedroom take the desirable north side, with one of them having to be exposed to the western side. The master bedroom is placed on the southern side, blocked on the undesirable west side by the ensuite, and features a balcony facing onto the street. This is a missed opportunity for the master bedroom to be on the most desirable aspect with a balcony overlooking the parklands to the north, and has therefore not met the clients' exact wishes. This could be altered but would incur extra fees and require substantial changes to the layout of the bathrooms, stairs and roof.

2 Pine Rivers 235 by GJ Gardener http://www.gjgardner.com.au/data/designs/12617_14.pdf 
b) Ventilation:

The open plan living area has opportunities for cross ventilation on three sides which help keep the house cool, but only through small windows and doors. The void over the stair may assist hot air escaping upwards through its small window, but not as effectively as the large void in the architect house. The bedrooms miss out on cross ventilation because windows are only placed on a single wall rather than both available sides. As bedroom 4 was removed to fulfil the clients need of an upstairs study, the upstairs area receives mild eastwest cross ventilation through its two modest windows.

\section{c) Solar:}

The lack of windows helps to reduce heat transfer from too much glass, but also reduces the amount of light, increasing the need for artificial light. Brick veneer is a good insulator and helps to keep the house cool, but is not ideal for the sub-tropical climate as it can retain heat during summer months. The concrete slab contains a great deal of thermal mass, which would not heat up from the sun as much as in the architect house, but also does not have an opportunity to vent from the lack of windows. $600 \mathrm{~mm}$ roof overhang helps reduce excess heat from the sun entering the house, but is insufficient for shading the downstairs area as well. This needs to be close to double in width similar to the architect house, or have awnings over the windows like the prefabricated house.

\section{Prefabricated House 3}

a) Orientation/Room arrangements:

As the prefabricated house is made up of modules, the design team has more flexibility with the placement of rooms and can place them essentially anywhere to suit the house. The modules can only be connected in certain ways, and any elements that have to be overly customised will add cost. The layout of the house downstairs is similar to the other two houses, with the garage placed separately on the east side to better reflect the architect house. This does not have as many advantages as the architect house because the bedrooms cannot be built on top to take advantage of the north-east orientation, and is rather a decision made simply because of the site's shape. The stair would have been better placed on the west side with the laundry and bathroom, but the modular nature of the stairs makes it difficult to achieve as it is a prefabricated piece. Other than these few facts the layout downstairs is quite good, but could benefit from more windows on the north side.

Upstairs is similar in layout to the developer house, with a study, 3 bedrooms and 2 bathrooms. Due to the location of the stair, two bedrooms have been placed on the west side and one on the east. The bathrooms are on the west side, but the ensuite is not in a position to shield the master bedroom from the western sun. Protruding blade walls on the west side assist in protecting this half of the house. In many ways the clients brief has not been satisfied, and is overall a cramped house.

\section{b) Ventilation:}

Cross ventilation is achievable downstairs, but is completely neglected upstairs except for the southern bedroom. The stair is able to vent hot air out but not to the extent of a double height void as seen in the architect house. Each bedroom has at least 2 windows and due to the light construction, would be a breeze filled house. The raised timber frame floor allows the underneath of the house to ventilate, which is a technique seen in the 'Queenslander' design common to Brisbane and surrounding areas.

\footnotetext{
${ }^{3}$ By Michael J. based on Happy Haus' Dhan series by Donovan Hill http://www.happyhaus.com.au/uploads/PLANS/Donovan\%20Hill/Base\%20Plans/Donovan\%20Hill\%20Happy\%20Haus\%20Floor\%20Plans .pdf
} 
c) Solar:

A lack of concrete slab means the prefabricated house has a very low thermal mass, and heat is able to escape easily from the floor. Timber clad walls all around mean heat is not retained within the house, but can still be sufficiently insulated to provide maximum efficiency. The roof has no overhangs except over the blade walls on the north and south sides. Instead, window hoods cover each window and can be different widths depending on the orientation of the window.

\section{Conclusion}

This focused research provides an insight into the implications of three key elements of sustainability; energy use, materials and thermal performance. Designers, builders, developers and home-buyers are given an insight into some options currently available on the housing market and how the choices made during early design stages can provide a more positive environmental impact.

It may be an ambitious proposition, but could site specific design that utilised prefabricated technology become the norm for suburban houses in south-east Queensland? By better utilising the knowledge of architects, research and software, all home-buyers will benefit from the advantages of choosing to live in a sustainable home. Software is a powerful tool for evaluating houses from the early design stages through to post-construction, and is being continuously updated to reflect more accurate results (Roy, Brown \& Gaze 2003). This software is becoming easier to use and more widely available so that the average person is able to make educated decisions with the help of their own computer.

Measuring the performance of a building is a complicated process due to the wide variety of impacting factors (Schneider \& Till 2005). Finding a common unit to quantify the results is difficult as different methods and equations are needed to convert the information to the same unit.

Analysing buildings with software can be extremely intricate and detailed. There are several software applications that can perform detailed analysis and there are companies that will carry out a study for a fee. This level of analysis is generally used for large scale buildings so detached housing misses out due to insignificant size.

This study has a common unit of measure as CO2e, which is not compatible for every aspect of building analysis, and can be very limiting when using software as a means of research. The study relies on the algorithms and equations built into the software to achieve the results in $\mathrm{CO} 2 \mathrm{e}$, so the accuracy is ultimately up to the program designers and their prior research and ongoing development.

The construction component has been taken out; this study does not look at the methods of construction that is prefabricated vs traditional construction, instead only looking at the design aspect and ongoing affects that people may be unaware of. The eTool is able to add construction specific details including machinery, man power, time, glues, nails, hammers, drills, saws, waste, bins, rainy days, delays etc. This would take a long time and would require more research into what is involved in the construction process of a specific house, but could add depth in future research.

Another important aspect of evaluating a building performance is the thermal comfort levels, as these figures can accurately determine whether mechanical heating or cooling is needed in the building. The software is very complicated, beyond the reach of this study, and would be suitable for future research of a similar kind. Free software is available, but there are currently compatibility problems between the modelling software and the analysis software. This issue will hopefully be resolved in the future, as there are already signs of it with exporters and file converters currently available. Some software still benefits from users modelling the building in their own format for optimisation and accuracy, which requires a 
new modelling skill set and misses out on being able to import already documented buildings.

Appliances and lighting has been exempted from this study so as to focus on the 3 main criteria. This information can be added to the appliance and lighting section in eTool and can test the difference made by efficient appliances. Ecodesigner is also able to add average figures to the analysis and be customised to test different efficiency ratings. By using energy efficient appliances, water saving taps, solar hot water, solar panels and only using electricity when needed, the house carbon footprint will be drastically improved.

The location of where the materials are manufactured can be added to the eTool software to create a more accurate $\mathrm{CO} 2 \mathrm{e}$, as the transportation of materials increases its carbon footprint. This could alter the results if the prefabricated house was, for instance, built in Sydney and transported via multiple trucks to Noosa for assembly.

Transport and how it is used will affect the ongoing performance of a house (Snyder 2005; Staib, Dörrhöfer \& Rosenthal 2008). This can be attributed to pre-design stages, when the site location of the house is being decided. Building a house in an area without public transport or which is great distances away from work, school, shops etc. will leave private transport as the only option. Further studies could include the transport required for the family living in the house to get to work, education, shopping and leisure, and will be greatly altered by distance and the types of transport available and utilised.

Costs are an important aspect of choosing a house, and as shown with the evaluated houses, the architect designed house is almost double the price of a developer house (Winstanley, Thorns \& Perkins 2002). Future research could include a breakdown of costs that explore the reasons why the architect house is more expensive than the developer house even after design fees have been excluded. The initial cost of implementing sustainable features is outweighed by the savings made by those sustainable features. What is the merit of designing a house the client actually wants, that may cost slightly more, but has less impact on the environment and ultimately will save money because of its performance, efficiency and cost saving over a specified period?

Based on the data from Ecodesigner and used in this study, though its accuracy is questionable, it shows an example of how currently an environmentally friendly house that has higher initial costs could end up saving money over a life span of 50 years. The higher initial cost may not be true for other prefabricated house designs and may be reduced in the future. It would also depend in part on builders overcharging for the use of technologies they do not commonly apply, but when the use of materials and technology becomes more established, costs are also reduced (Manseau \& Shields 2005).

A limitation of this study is its reliance on rating systems. Although there is no consensus on the value and efficiency of these tools (Gowri 2004), this research has used the selected software as a way to compare, in an objective way, three different design propositions. Future research might address the issue of the difference between planned and actual performances of buildings. This study has attempted to gather a better understanding of how different design strategies and methodology could ideally perform in a specific location.

The results of the study indicate that architecturally designed housing, especially when married with prefabricated building techniques, are a better alternative to generic developer style housing. Rethinking the types of materials houses are constructed with, and the ways in which they are constructed will ensure the future development and improvement of sustainable design, with technological advances becoming accessible for the average Australian. 


\section{References}

Arif, M. \& Syal, M. 2013, 'Addressing Global Changes for a Sustainable Built Environment: Implementing Sustainable Construction', Construction Innovation, 13.

Birkeland, J. 2002, Design for sustainability: a sourcebook of integrated, eco-logical solutions, Earthscan, London.

Blismas, N. \& Wakefield, R. 2009, 'Drivers, constraints and the future of offsite manufacture in Australia', Construction Innovation: Information, Process, Management, 9, 72-83.

Callery, B. \& Bartak, E. 2010, 'Brighton Compact Green House: Case Study', Houses Magazine.

Davies, C. 2005, The prefabricated home, Reaktion, London.

Discoe, P., Quinn, A. \& Banish, R. 2008, Zen Architecture: The Building Process as Practice, Gibbs Smith Publishers.

Divecha, S., Muffet, L. \& Grant, T. 2008, 'Mawson Lakes Footprint Report', Strategic Matters, GreedMode and RMIT.

Eco-Logical Building. n.d.. Available from http://www.ecologicalbuilding.com.au.

Gowri, K. 2004, 'Green building rating systems: An overview', ASHRAE Journal, 46, 56.

Johnson, L. 2014, 'Accommodating Australians. Commonwealth Government Involvement in Housing: Designer Suburbs. Architects and Affordable Homes in Australia', Journal of Australian Studies, 38, 120-3. doi: http://dx.doi.org/10.1080/14443058.2013.871679

Kaufmann, M. \& Remick, C. 2009, Prefab Green, Gibbs Smith, Layton, UT, USA.

Kendall, S. 1999, 'Open building: an approach to sustainable architecture', Journal of Urban Technology, 6, 1-16. doi: http://dx.doi.org/10.1080/10630739983551

Kibert, C. J. 2008. Sustainable construction: green building design and delivery (2rd Ed), Hoboken, NJ, John Wiley \& Sons, Inc.

Kibert, C.J. 2012, Sustainable construction: green building design and delivery, John Wiley \& Sons, Inc. Hoboken, NJ.

Koenig, G., Eames, C. \& Eames, R. 2005, Charles \& Ray Eames 1907-1978, 1912-1988: Pioneers of Mid-century Modernism, Taschen, Cologne, Germany.

Linner, T. \& Bock, T. 2012, 'Evolution of large-scale industrialisation and service innovation in Japanese prefabrication industry', Construction Innovation, 12, 156-78. doi: http://dx.doi.org/10.1108/14714171211215921

Manseau, A. \& Shields, R. 2005, Building tomorrow: innovation in construction and engineering, Aldershot, Hants, Ashgate, England.

McHarg, I.L. 1981, 'Human ecological planning at Pennsylvania', Landscape Planning, 8, 109-20. doi: http://dx.doi.org/10.1016/0304-3924(81)90029-0

MacMillan, A. 2006. How to recycle anything. Prevention, April, 119-121

Moore, T. 2010, 'Brisbane's suburbs of growth and decline', Brisbane Times, http://www.brisbanetimes.com.au/business/property/brisbanes-suburbs-of-growth-and-decline20101103-17e71.html.

Newman, P. \& Kenworthy, J. 1999, Sustainability and cities: overcoming automobile dependence, Island Press, Washington, DC.

Oluwole Akadiri, P. \& Olaniran Fadiya, O. 2013, 'Empirical analysis of the determinants of environmentally sustainable practices in the UK construction industry', Construction Innovation, 13, 352-73. doi: http://dx.doi.org/10.1108/Cl-05-2012-0025

Öst, C.E. 2012, 'Housing and children: simultaneous decisions?-a cohort study of young adults' housing and family formation decision', Journal of Population Economics, 25, 349-66. doi: http://dx.doi.org/10.1007/s00148-010-0345-5 
Roy, R., Brown, J. \& Gaze, C. 2003, 'Re-engineering the construction process in the speculative house-building sector', Construction Management \& Economics, 21, 137-46. doi: http://dx.doi.org/10.1080/0144619032000049674

Schneider, T. \& Till, J. 2005, 'Flexible housing: opportunities and limits', Architectural Research Quarterly, 9, 157-66. doi: http://dx.doi.org/10.1017/S1359135505000199

Shulman, J., Smith, E.A.T. \& Gössel, P 2007, Taschen, Case Study Houses, Cologne, Germany.

Snyder, V. 2005, 'Refabricating Architecture: How Manufacturing Methodologies are Poised to Transform Building Construction', Journal of Architectural Education, 59, 51-2. doi: http://dx.doi.org/10.1111/j.1531-314X.2005.00008.x

Staib, G., Dörrhöfer, A. \& Rosenthal, M. 2008, Components and Systems: Modular Construction Design, Structure, New Technologies, Walter de Gruyter, Berlin. doi: http://dx.doi.org/10.11129/detail.9783034615662

Urban Development Institute of Australia 2014. UDIA Submission to the Senate Inquiry into Affordable Housing, 31 March 2014.

Van Der Ryn, S. \& Cowan, S. 2007, Ecological design, Island Press, London.

Winstanley, A., Thorns, D.C. \& Perkins, H.C. 2002, 'Moving house, creating home: Exploring residential mobility', Housing Studies, 17, 813-32. doi: http://dx.doi.org/10.1080/02673030216000

Wood, R. 2009, 'Structural decomposition analysis of Australia's greenhouse gas emissions', Energy Policy, 37, 4943-48. doi: http://dx.doi.org/10.1016/j.enpol.2009.06.060

Zhang, S., Pan, Y., Li, N. \& Sun, Q. 2014, 'A Comparative Study of the Direct Costs Between Prefabricated Housing System and the Traditional Construction Technology-A Case Study of Precast Concrete Wall Panel', Proceedings of the 18th International Symposium on Advancement of Construction Management and Real Estate, Springer, 349-58. doi: http://dx.doi.org/10.1007/9783-642-44916-1 35 